Jurnal Sistem Informasi (Journal of Information Systems). 2/12 (2016), 82-89

DOI: http://dx.doi.org/10.21609/jsi.v12i2.481

\title{
VISUALISASI DATA INTERAKTIF DATA TERBUKA PEMERINTAH PROVINSI DKI JAKARTA: TOPIK EKONOMI DAN KEUANGAN DAERAH
}

\author{
Nadiar Ahmad Syaripul dan Adam Mukharil Bachtiar \\ Teknik Informatika, Fakultas Teknik dan Ilmu Komputer, Universitas Komputer Indonesia, \\ Jalan Dipatiukur No. 112-116, Bandung, 40132, Indonesia \\ Email: nadiar429@email.unikom.ac.id,adam@email.unikom.ac.id
}

\begin{abstract}
Based on statistics from data.id, in the first quarter of 2016, there are 1,137 datasets distributed at 32 institutions and 18 groups in Indonesia. DKI Jakarta Province contributes to these data at the most, i.e. 714 datasets. A lot of accessible open datasets have an impact on the availability of valuable information that can be extracted to good use, for businesses, governments, and personal lives. To get the desired information, an exploratory data analysis is needed to make data more alive. The goal of this research is to provide a proper visualization of the given data. Data visualization is a way (perhaps a solution) to communicate abstract data, to aid in data understanding by leveraging human visual system. The result of this visualization is effective and engaging charts appropriates to the given data and can be run on mobile platforms.
\end{abstract}

Keywords: visualization, open data, information, exploratory data analysis, mobile platform

\begin{abstract}
Abstrak
Berdasarkan statistik data.id, di kuartal pertama 2016, data terbuka yang tersedia di Indonesia sebanyak 1.137 dataset yang tersebar di 32 instansi dan 18 grup. Provinsi DKI Jakarta menjadi provinsi yang paling banyak memberikan kontribusi dataset, yaitu sebanyak 714. Banyaknya dataset terbuka yang bebas diakses berdampak pada informasi berharga yang bisa didapatkan dan dimanfaatkan untuk keperluan bisnis, pemerintahan, ataupun pribadi. Untuk mendapatkan informasi tersebut, analisis eksplorasi data diperlukan untuk membuat data lebih hidup. Tujuan penelitian ini membuat visualisasi yang tepat dari data yang diberikan. Visualisasi data adalah cara (solusi) mengkomunikasikan data abstrak, membantu pemahaman data dengan memanfaatkan sistem visual manusia. Hasil visualisasi ini adalah grafik yang efektif dan menarik yang tepat untuk data dan berjalan di atas platform mobile.
\end{abstract}

Kata Kunci: visualisasi, data terbuka, informasi, analisis eksplorasi data, mobile platform

\section{Pendahuluan}

Pada era digital saat ini, menemukan data tidaklah begitu sulit; data (dataset) dapat ditemukan di internet. Dataset tersebut sangatlah besar, kompleks, dan sulit dianalisis dengan perangkat lunak data processing seperti spreadsheet [1]. Pemerintah Provinsi DKI Jakarta menyediakan dataset yang bebas didistribusikan, disimpan, dan dikelola. Dataset seperti ini dikenal dengan istilah "open data" (data terbuka) [2].

Data ekonomi dan keuangan daerah menggambarkan data tentang pertumbuhan ekonomi dan hasil kinerja pemerintah, data ini ada sebagai upaya transparansi pemerintah baik kepada pelaku ekonomi maupun pelaku non-ekonomi. Berdasarkan hasil kuesioner terbuka yang dilakukan pada tanggal 25 Agustus 2015 s.d. 27 Agustus 2015 dengan segmentasi responden pelaku UKM di Jakarta, 78.05 $\%$ responden tidak bisa mengambil insight dari da- ta, $21.95 \%$ yang dapat mengambil insight dari data, dan 100\% responden setuju jika visual analisis diperlukan. Kesimpulannya mayoritas responden setuju bahwa data yang disajikan dalam tempat penyimpanan data Pemerintah Provinsi DKI Jakarta masih sulit dibaca dan dimengerti.

Cara efektif menyajikan data yang detail menjadi informasi yang mudah diterima adalah dengan cara abstraksi menjadi informasi visual. Visualisasi melalui perumpamaan visual dari dulu hingga saat ini telah digunakan sebagai teknik penyimpanan pesan. Dahulu perumpamaan visual berbentuk simbol-simbol yang merepresentasikan suatu makna. Visualisasi mengubah data menjadi informasi yang bisa dimengerti secara universal [3].

Penelitian ini menggunakan pustaka nvD3.js dalam implementasi grafik dinamis dan interaktif. Grafik diimplementasikan di atas platform hybrid aplikasi mobile menggunakan framework ionic 2. Data yang digunakan dalam aplikasi mobile diam- 


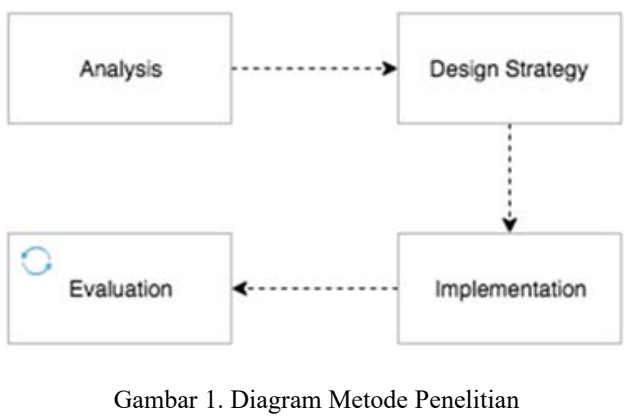

bil langsung dari flat file tempat penyimpanan data terbuka DKI Jakarta. Data tersebut diperbarui dengan rentang waktu tertentu menggunakan cronjob.

\section{Metode}

\section{Tahapan Pengembangan Penelitian}

Penelitian ini merupakan penelitian pengembangan dengan tahapan sebagaimana ditunjukkan pada Gambar 1.

\section{Analysis}

Langkah pertama yang dilakukan adalah melakukan analisis masalah, analisis kebutuhan pengguna, dan analisis pemilihan algoritma. Analisis masalah dilakukan untuk mencari tahu permasalahan pengguna open data topik ekonomi dan keuangan daerah. Analisis kebutuhan pengguna dilakukan untuk memastikan kebutuhan pengguna terhadap data. Sementara itu, analisis pemilihan algoritma dilakukan untuk memilah algoritma paling efisien sesuai sumber daya yang tersedia dan kebutuhan pengguna.

Design Strategy

Berdasarkan analisis yang diperoleh, kemudian dibuatlah strategi pemecahan masalah, strategi ini meliputi strategi perancangan data dan perancangan arsitektur.

\section{Implementation}

Design Strategy diimplementasikan pada data dan teknologi arsitektur yang sudah dipilih.

\section{Evaluation}

Evaluasi berkelanjutan yang dilakukan pengembang untuk terus menyempurnakan sistem.

\section{Batasan Masalah}

Karena data yang sangat banyak dan terpisah-pisah dilakukan batasan dalam pengambilan data, yaitu sebanyak 12 data pada topik ekonomi dan keuang-

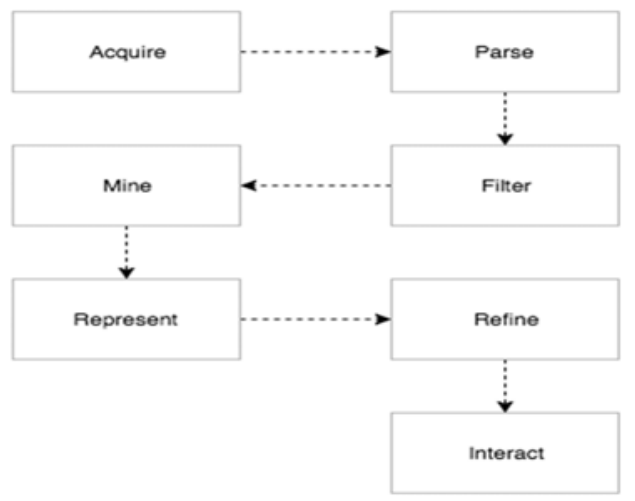

Gambar 2. Proses visualisasi data menurut Ben Fry dalam buku yang berjudul "Visualizing Data"

an daerah, dengan memilah data yang paling populer berdasarkan activity stream repositori. Adapun data yang digunakan tertera pada Lampiran Tabel I.

\section{Proses Visualisasi Data}

Visualisasi data sama halnya seperti berkomunikasi, berhasil atau tidaknya komunikasi ditentukan oleh bagaimana cara pembicara menyampaikan informasi yang diberikan kepada lawan komunikasi. Visualisasi yang baik tentu terfokus, memberikan jawaban yang jelas, dan tidak terlalu detail. Untuk mencapai visualisasi yang baik dilakukan proses visualisasi data [4], proses visualisasi data yang digunakan adalah sebagaimana ditunjukkan pada Gambar 2.

Acquire meliputi proses pengambilan data, baik dari internet ataupun dari disk lokal. Parse merupakan proses memberikan struktur data yang tepat pada data yang akan diolah. Filter merupakan proses memilah-milah data yang sesuai dengan tujuan yang akan dicapai. Mine meliputi proses melakukan analisis statistik atau data-mining terhadap data untuk mencapai tujuan. Proses ini bersifat pilihan. Represent merupakan proses merubah data yang berbentuk teks menjadi grafik dasar yang sesuai. Refine adalah proses memperkaya grafik dasar dengan berbagai visual encoding. Proses ini bersifat pilihan. Interact adalah proses merubah grafik statis menjadi grafik dinamis. Proses ini juga bersifat pilihan.

\section{Exploratory Data Analysis}

Exploratory Data Analysis (EDA) adalah proses menggali intuisi (memahami) terhadap data yang digunakan, apakah data ini dan untuk apa data ini [5]. Pada penelitian ini, EDA digunakan untuk menjawab kebutuhan informasi dari setiap data (ex- 

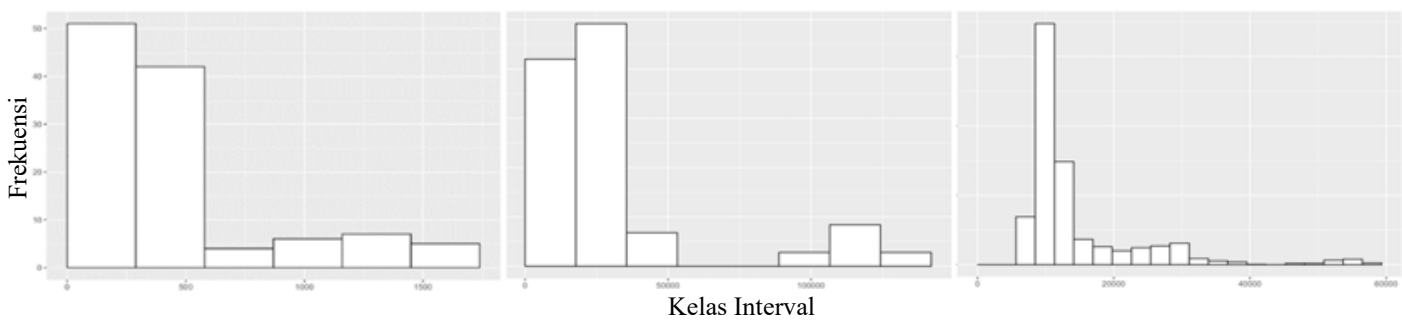

Gambar 3. Histogram untuk Data 8, Data 10, dan Data 11
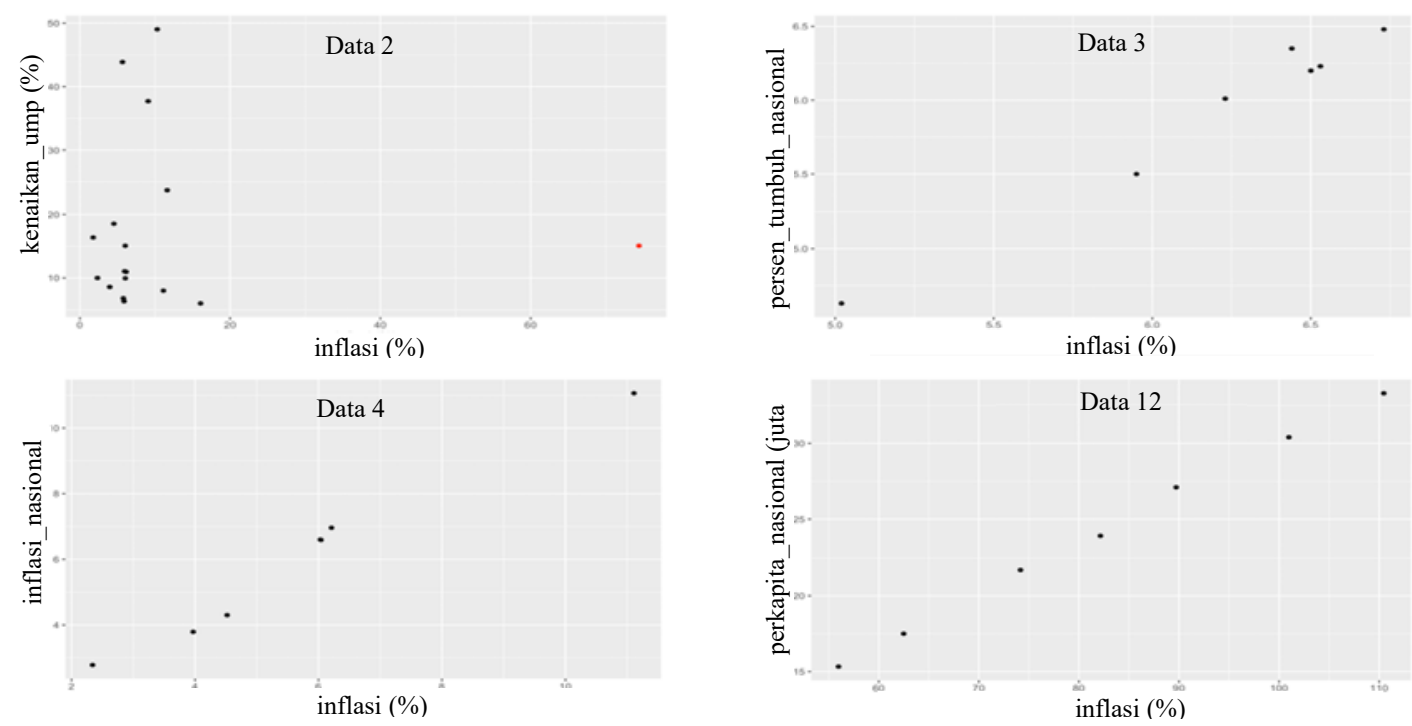

Gambar 4. Scatter plot untuk Data 2, 3, 4, dan 12

tract infromation from the data). Kebutuhan informasi tersebut selanjutnya dipetakan terhadap metode statistik atau algoritma tertentu (pemecahan masalah) sebelum dilakukan visualisasi. Adapun kebutuhan informasi dan metode pemecahan masalah ditunjukan pada Lampiran Tabel II.

Untuk data yang tidak terdapat pada Lampiran Tabel II, visualisasi langsung didapatkan tanpa melalui proses pemecahan masalah (proses Mine).

\section{Hasil dan Analisis}

Data 1 dan Data 9 menunjukkan angka-angka statistik secara ekplisit, sehingga permasalahan dapat dijawab secara langsung dan sederhana melalui statistik dalam bentuk bar chart atau pie chart [6].

\section{Histogram}

Histogram digunakan pada Data 8, Data 10, dan Data 11 (Gambar 3). Histogram dipakai untuk menggambarkan distribusi terhadap suatu field pada data tersebut [7]. Panjang interval pada histogram dihitung dengan formula scott [8], yaitu:

$$
h=\frac{3.5 \sigma}{n^{1 / 3}}
$$

Kelas interval dan frekuensi untuk Data 8, Data 10, dan Data 11 adalah sebagaimana ditunjukkan pada Lampiran Tabel 3, 4, dan 5.

\section{Linear Regression}

Linear regression digunakan untuk membuat model linear dua variabel atau lebih, dengan tujuan untuk mencari tahu hubungan antara variabel yang dimodelkan tersebut [9]. Berdasarkan atribut, tipe data, jumlah field, dan nilai korelasi $r$ [9] yang cukup tinggi yang terdapat pada setiap data, untuk mencari tahu bagaimana trend setiap periode maka digunakan metode linear regression.

Pada penelitian ini, linear regression digunakan untuk Data 2, Data 3, Data 4, dan Data 12. Jumlah variabel yang hendak dimodelkan untuk Data 2, Data 3, Data 4, dan Data 12 berjumlah dua variabel, sehingga model linear yang hendak dibuat yaitu seperti diberikan pada persamaan(2).

$$
f(x)=\beta_{1} x+\beta_{0}
$$



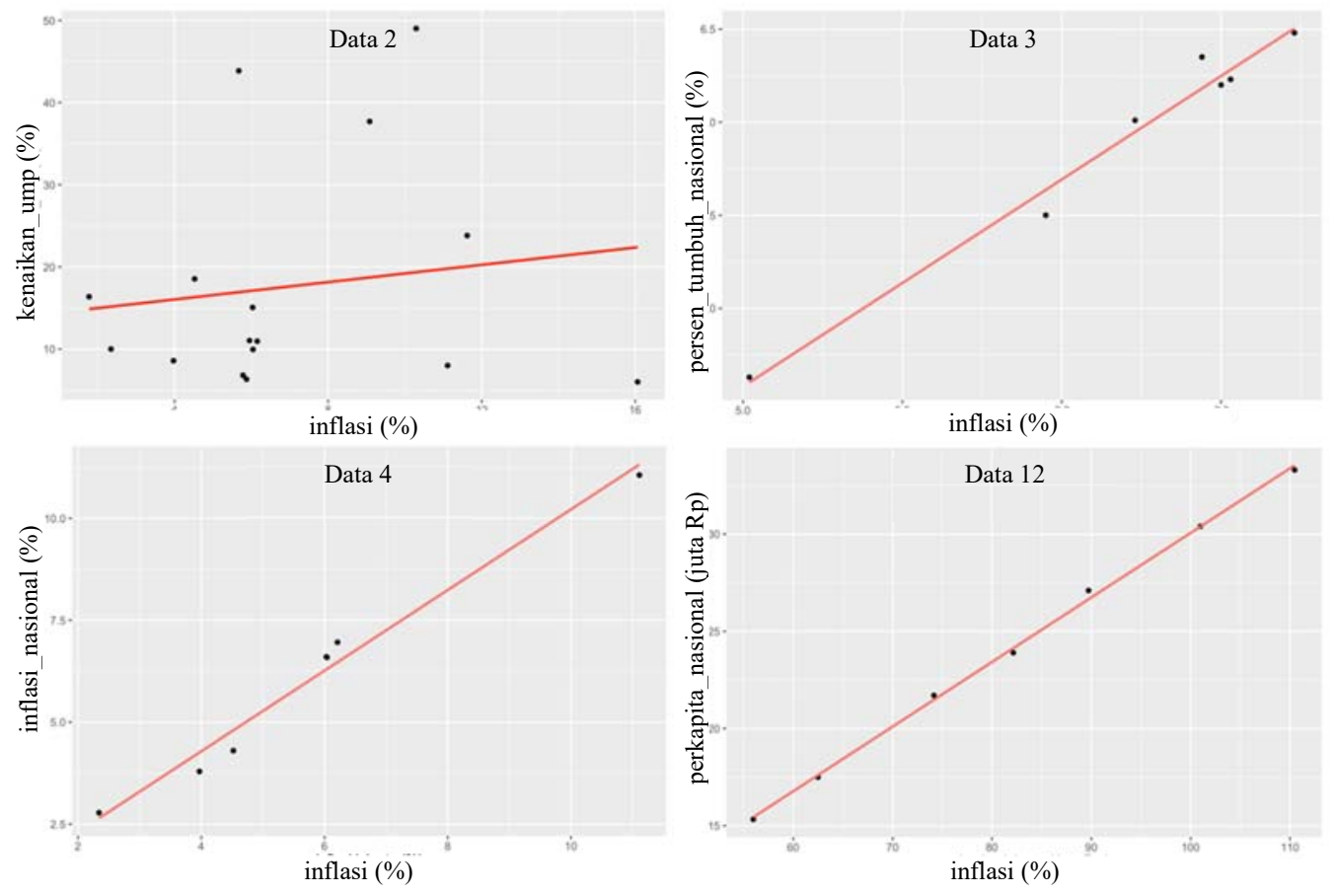

Gambar 5. Scatter plot dan model linear untuk Data 2, 3, 4, dan 12

$\beta_{1}$ pada persamaan(2) merupakan gradien garis linear, dan $\beta_{0}$ adalah intercept. $\beta_{1}$ didapatkan dari persamaan(3).

$$
\beta_{1}=r \frac{\sigma_{y}}{\sigma_{x}}
$$

$r$ adalah correlation coefficient, yang didapatkan dari persamaan(4) dan $\sigma$ adalah sample standard deviation.

$$
r=\frac{n\left(\sum x y\right)-\left(\sum x\right)\left(\sum y\right)}{\sqrt{\left(n \sum x^{2}-\left(\sum x\right)^{2}\right)\left(n \sum y^{2}-\left(\sum y\right)^{2}\right)}}
$$

Pemodelan yang dibuat untuk Data 2 adalah memodelkan atribut kenaikan_ump dari atribut inflasi, untuk Data 3 memodelkan atribut persen tumbuh_nasional dari atribut persen_tumbuh_jakarta, untuk Data 4 memodelkan atribut inflasi_nasional dari atribut inflasi_jakarta, dan untuk Data 12 memodelkan atribut perkapita_nasional dari atribut perkapita_jakarta. Scatter plot pada Data 2, Data 3, Data 4, dan Data 12 adalah sebagaimana ditunjukkan pada Gambar 4.

Untuk plot pada Data 2, terlihat bahwa terdapat outlier. Outlier tersebut akan dihilangkan untuk membuat model lebih baik.

Dari hasil perhitungan, model linear untuk Data 2 adalah $y=0.5265 x+13,937$ dengan nilai $r$ sebesar 0.1439, model linear untuk Data 3 adalah $y=1.263 x-2.062$ dengan nilai $r$ sebesar 0.9078 , model linear untuk Data 4 adalah $y=$ $0.9889 x+0.3296$, dengan nilai $r$ sebesar 0.9892 , dan model linear untuk Data 12 adalah $y=$ $0.3322 x-3.1573$ dengan nilai $r$ sebesar 0.9993 . Gambar 5 menunjukkan plot model linear untuk setiap data.

\section{K-Means}

K-Means adalah algoritma yang digunakan untuk melakukan pengelompokan data ke dalam bentuk dua atau lebih kelompok. Tujuan pengelompokan adalah meminimalkan variasi di dalam suatu kelompok dan memaksimalkan variasi antarkelompok [10].

Pada platform yang memiliki sumber daya terbatas dan untuk meminimalkan waktu latensi, efisiensi sumber daya sangat diperlukan. Untuk mencapai performa terbaik maka diperlukan algoritma clustering yang memiliki efesiensi yang cukup baik. Dibandingkan metode clustering lain seperti teknik herarchical, $k$-Means memiliki performa $O(n)$ sedangkan teknik herarchical memiliki performa $O(n 2)$ [11].

Data 7 dibagi ke dalam tiga kelompok. $k$ Means digunakan pada Data 7 dengan tujuan untuk meminimalkan variasi setiap kelompok. Data keluaran $k$-Means selanjutnya akan divisualisasikan menggunakan pie chart seperti ditunjukkan pada 
Gambar 6. Berikut merupakan algoritma $k$-Means [10]:

1) Tentukan jumlah kelompok $k$.

2) Tentukan titik pusat klaster $k$ (centroid) secara acak pada ruang $d$ dimensi.

3) Kelompokan data sehingga terbentuk k buah klaster dengan titik centroid dari setiap klaster merupakan titik centroid yang telah dipilih sebelumnya.

4) Kelompokan setiap titik ke dalam $k$-set centroid paling dekat, yaitu dengan cara menghitung jarak setiap titik dengan pusat klaster. Persamaannya ditunjukkan pada persamaan (5).

$$
\operatorname{dist}\left(x_{1}, x_{2}\right)=\sqrt{\sum_{j=1}^{p}\left|x_{2 j}-x_{1 j}\right|^{2}}
$$

5) Perbaharui setiap centroid dengan rata-rata (mean) titik pada klaster tersebut, yaitu titiktitik yang sudah dikelompokan sebelumnya.

6) Ulang langkah ke-4 dan ke-5 sampai pengelompokan tidak berubah.

Pada Data 7, atribut yang menjadi titik-titk dalam $k$-Means adalah atribut volume dan nilai. Inisialisasi nilai centroid untuk klaster $k_{1}$ adalah (301900.47, 3933797.8). Sedangkan untuk $k_{2}$ dan $k_{3}$ adalah $(42286.14,102493.1)$ dan (440518.57, 977354.3) berturut-turut.

Setelah iterasi pertama, didapatkan $k_{1}$ sebanyak 160 observasi $(82.05 \%), k_{2}$ sebanyak 22 observasi $(11.28 \%)$, dan $k_{3}$ sebanyak 12 observasi $(6.15 \%)$. Setelah iterasi ke-2 didapatkan bahwa $k_{1}$ sebanyak 165 , observasi $(84.62 \%), k_{2}$ sebanyak 17 observasi $(8.7628 \%)$, dan $k_{3}$ sebanyak 12 observasi (6.1855\%); Setelah iterasi ke-3 didapatkan bahwa $k_{1}$ sebanyak 165 , observasi $(84.62 \%), k_{2}$

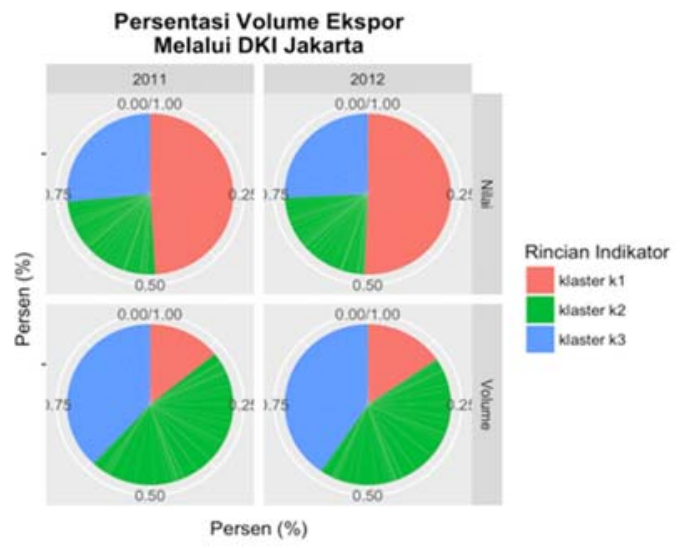

Gambar 6. Pie chart digunakan untuk memudahkan pengguna membandingkan data di setiap klaster sebanyak 17 observasi $(8.7628 \%)$, dan $k_{3}$ sebanyak 12 observasi $(6.15 \%)$. Setelah iterasi ke-2, pengelompokan tidak berubah. Gambar 7 menunjukan plot final hasil pengelompokan $k$-Means. Lampiran Tabel 6 menunjukan statistik atribut yang dihitung per klaster.

\section{Arsitektur Sistem}

Perancangan arsitektur (Gambar 8) menjelaskan bagaimana sistem bekerja secara abstrak. Terdapat dua subsistem yang bekerja, restfull service dan subsistem mobile. Pada subsistem mobile, request data akan dikirim ke-restfull service, setelah itu restfull service akan memeriksa apakah data yang diminta. Jika data tersedia, restfull service akan memberikan response sesuai data yang diminta dan dikirim dalam bentuk format data json. Selanjutnya subsistem mobile akan mengolah data json menjadi visualisasi.

\section{Maintainer}

Maintaner adalah pengelola yang mengelola perangkat lunak, menangani bugs dan pengembangan perangkat lunak. Maintainer dapat melakukan metode POST, GET, PUT, PATCH, dan DELETE melalui protokol HTTP.

\section{Cron Job}

Cron Job adalah sebuah task scheduler yang akan memeriksa secara berkala apakah terdapat perubahan pada Jakarta Open Data melalui R Server. Jika terdapat perubahan, Cron Job akan melakukan HTTP request yang sesuai ke RESTful Server.

\section{R Server}

$\mathrm{R}$ Server adalah server yang melakukan analisis terhadap data yang di-download dari Jakarta Open Data. Pada R Server juga algoritma diimplementasikan. Sehingga hasil keluaran dari analisis adalah data dalam format json yang siap di parse menjadi visualisasi.

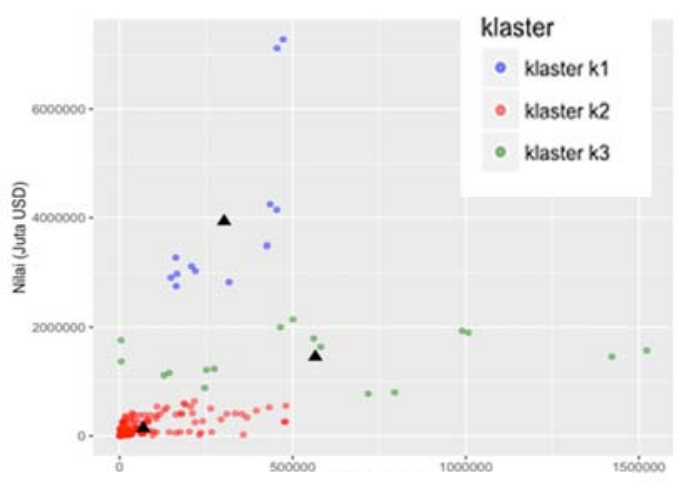

Gambar 7. Plot final keluaran $k$-Means 


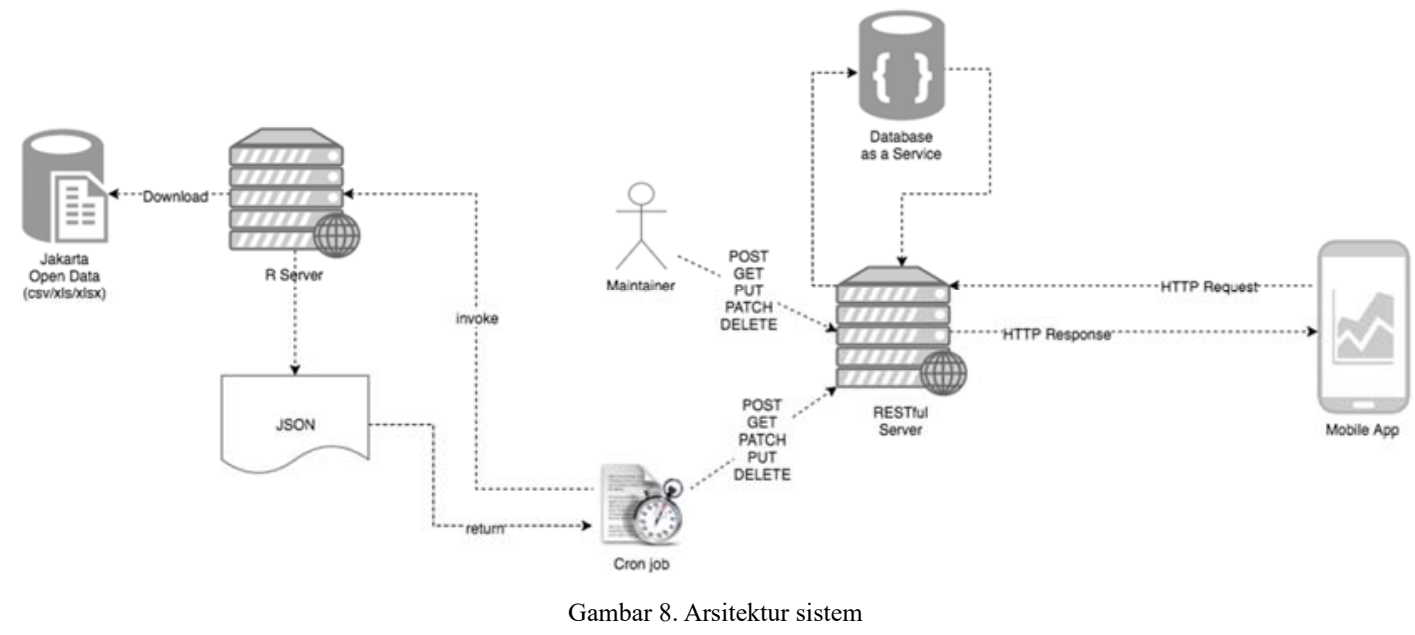

Jakarta Open Data

Jakarta Open Data adalah adalah tempat penyimpanan (repository) data terbuka (open data) Pemerintah Provinsi DKI Jakarta. Data yang ada pada Jakarta Open Data dalam format flat file csv, xls, atau xlsx.

\section{RESTful server}

RESTful server adalah server yang meng-host sekaligus menjalankan RESTful API. Data disimpan terpisah pada platform Database as a Service.

Database as a Service

Database as a Service adalah server basis data yang digunakan dalam penyimpanan hasis analisis R Server.

\section{Mobile app}

Mobile app adalah aplikasi visualisasi yang didesain untuk platform mobile, data untuk aplikasi dibaca dari RESTful API melalui protokol HTTP. Gambar Lampiran 1 pada Lampiran adalah contoh beberapa potret visualisasi data pada aplikasi mobile yang dibangun.

\section{Kesimpulan}

Visualisasi interaktif berbasis mobile digunakan untuk memudahkan membaca informasi data terbuka Pemprov DKI Jakarta topik ekonomi dan keuangan daerah. Platform mobile dipilih karena memiliki keunggulan praktis. Selain itu, platform dibangun di atas framework ionic 2, yang mana memiliki keunggulan bisa di-install tidak terbatas pada satu jenis platform mobile saja.

Pada post kuesioner yang dilakukan pada tanggal 5 Agustus 2016 s/d 10 Agustus 2016 dengan responden yang sama, sebanyak $83.6 \%$ responden dapat membaca analisis visual dan mengambil insight dari data, sebanyak $14.0 \%$ responden dapat membaca analisis visual tetapi tidak dapat mengambil insight, dan sebesar $2.4 \%$ responden tidak dapat membaca analisis visual. $2.4 \%$ responden yang tidak dapat membaca analisis visual bukan karena visualisasi yang buruk, tetapi lebih karena faktor teknis pada platform yang digunakan.

Kelemahan dari aplikasi visualisasi mobile ini terletak pada penanganan pembaharuan data (error handling) melalui script corn-job, di mana script cron-job hanya bisa menangani data yang tersimpan pada berkas yang sama. Artinya, ketika data yang baru tersedia pada berkas yang berbeda, maka, pembaharuan data harus dilakukan secara manual. Kelemahan lain terletak pada hybird platform ionic 2, yang memiliki performa kurang baik untuk beberapa case pengguna seperti crash.

Visualisasi data bukanlah hal yang baru, berbagai visualisasi data yang memberikan narasi yang bagus terhadap data banyak ditemukan, namun tidak banyak visualisasi data yang baik yang bersumber dari data terbuka (open data) Indonesia. Penelitian visualisasi data kedepannya bisa diaplikasikan tidak terbatas menggunakan data topik ekonomi dan keuangan daerah saja.

\section{Referensi}

[1]. C. Snijders, U. Matzat and U.-d. Reips, "'Big Data": Big Gaps of Knowledge in the Field of Internet Science," International Journal of Internet Science, vol. 7, no. 1, pp. 1-5, 2013.

[2]. Anon, "The Open Definition," [Online]. Available: http://opendefinition.org/. [Accessed 03 October 2015].

[3]. I. J. Asmara, E. Achelia, W. Maulana, R. Wijayanti and Y. Rianto, "Teknik Visualisasi Grafik Berbasis Web di Atas Platform Open Source," Seminar Nasional Aplikasi Teknologi Informasi 2009 (SNATI 2009), pp. 4447, 2009.

[4]. B. Fry, Visualizing Data, O'Reilly, 2007, pp. 5-14. 
[5]. C. O'Neil and R. Schutt, Doing Data Science, O'Reilly, 2013, pp. 34-37.

[6]. A. Abela, "Chart Suggestions-A thoughtstarter," in Extreme Presentation, 2009.

[7]. D. C. Montgomery and G. C. Runger, Applied Statistics and Probability for Engineers Third Edition, Jhon Wiley \& Sons, 2002, pp. 203-206.

[8]. D. W. Scott, "On Optimal and Data-Based Histograms," Biometrika, vol. 66, no. 3, pp. 605-610, 1979.
[9]. A. M. Glenberg and M. E. Andrzejewski, Learning from Data, an Introduction to Statistical Reasoning, 3rd Edition ed., New York: Lawrence Erlbaum Associates, 2008, pp. 477-496.

[10]. H. Jiawei, M. Kamber and J. Pei, Data Mining: Concepts and Techniques, Third Edition, Waltham: Elsevier, 2012, pp. 451-454.

[11]. M. Steinbach, G. Karypis and V. Kumar, "A Comparison of Document Clustering Techniques," in KDD workshop on text mining, 2000 .

\section{Lampiran}

LAMPIRAN TABEL II

PEMETAAn KeBUtUhan INFORMASI TERHADAP ALGORITMA/STATISTIK

\begin{tabular}{lll}
\hline Kebutuhan Informasi & Data & Pemecahan \\
\hline Seberapa besar sumber daya telah dimanfaatkan di dalam kegiatan ekonomi. & 1,9 & Statistik \\
Bagaimana trend variabel-variabel ekonomi mengalami pergerakan & $2,3,4,12$ & Linear Regression \\
Bagaimana distribusi harga suatu komoditas. & $8,10,11$ & Histogram \\
Seberapa besar permintaan atau penawaran terhadap komoditas. & 7 & $k$-Means \\
\hline
\end{tabular}

LAMPIRAN TABEL III KELAS INTERVAL DAN FREKUENSI DATA 8

\begin{tabular}{ll}
\hline Kelas Interval & Frekuensi \\
\hline $0-289.93$ & 51 \\
$289.94-579.87$ & 42 \\
$579.88-869.81$ & 4 \\
$869.82-1159.75$ & 6 \\
$1159.76-1449.69$ & 7 \\
$1449.70-1739.63$ & 5 \\
\hline
\end{tabular}

LAMPIRAN TABEL IV KELAS INTERVAL DAN FREKUENSI DATA 10

\begin{tabular}{ll}
\hline Kelas Interval & Frekuensi \\
\hline $0-17753.08$ & 105 \\
$17753.09-35506.17$ & 123 \\
$35506.18-53259.26$ & 17 \\
$53259.27-71012.35$ & 0 \\
$71012.36-88765.44$ & 0 \\
$88765.45-106518.50$ & 7 \\
$106518.51-124271.60$ & 21 \\
$124271.60-142024.70$ & 7 \\
\hline
\end{tabular}

LAMPIRAN TABEL V KELAS INTERVAL DAN FREKUENSI DATA 11

\begin{tabular}{ll}
\hline Kelas Interval & Frekuensi \\
\hline $0-2825.27$ & 0 \\
$2825.28-5650.55$ & 0 \\
$5650.56-8475.83$ & 138 \\
$8475.84-11301.12$ & 695 \\
$11301.13-14126.40$ & 297 \\
$14126.41-16951.68$ & 73 \\
$16951.69-19776.96$ & 52 \\
$19776.97-22602.24$ & 40 \\
$22602.25-25427.52$ & 49 \\
$25427.53-28252.80$ & 54 \\
$28252.81-31078.08$ & 62 \\
$31078.09-33903.36$ & 18 \\
$33903.37-36728.64$ & 11 \\
$36728.65-39553.92$ & 8 \\
$39553.93-42379.20$ & 1 \\
$42379.21-45204.48$ & 0 \\
$45204.49-48029.76$ & 4 \\
$48029.77-50855.04$ & 4 \\
$50855.05-53680.32$ & 13 \\
$53680.33-56505.60$ & 16 \\
$56505.61-59330.88$ & 5 \\
\hline
\end{tabular}

LAMPIRAN TABEL VI

StATISTIK ATRIBUT PER KLASTER

\begin{tabular}{ccccccc}
\hline \multirow{2}{*}{ Klaster } & \multicolumn{2}{c}{ Max } & \multicolumn{2}{c}{ Min } & \multicolumn{2}{c}{ Mean } \\
\cline { 2 - 7 } & volume & nilai & volume & nilai & volume & nilai \\
\hline Klaster $k_{1}$ & 472300.3 & 7281767 & 148100.1 & 2756790 & 301900.5 & 3933798 \\
Klaster $k_{2}$ & 480066.6 & 634643 & 20.62 & 3.85 & 68058.43 & 138135.5 \\
Klaster $k_{3}$ & 1522428 & 2140779 & 774358.9 & 4056.31 & 565182.8 & 1454812 \\
\hline
\end{tabular}




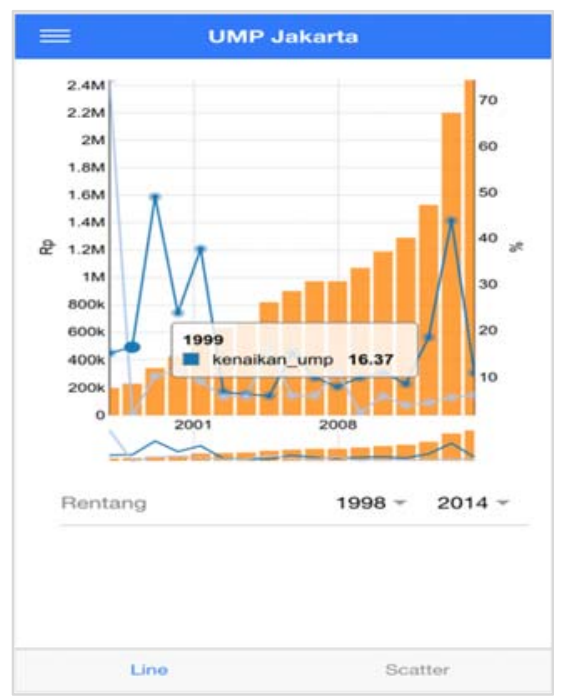

(a)

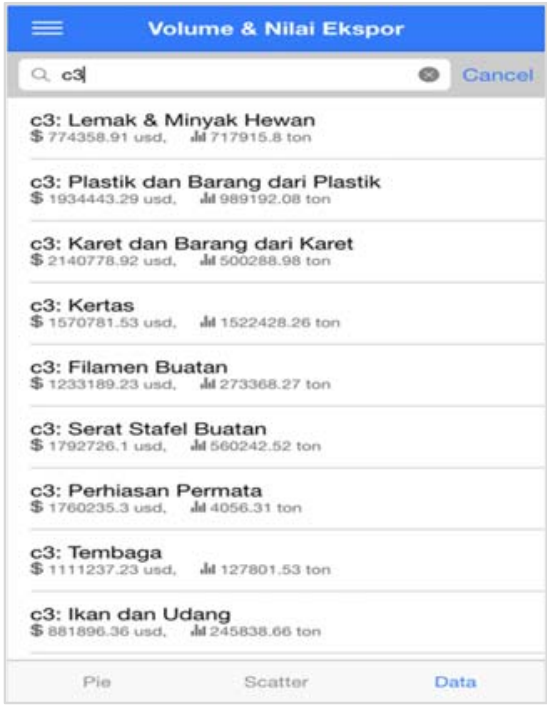

(c)

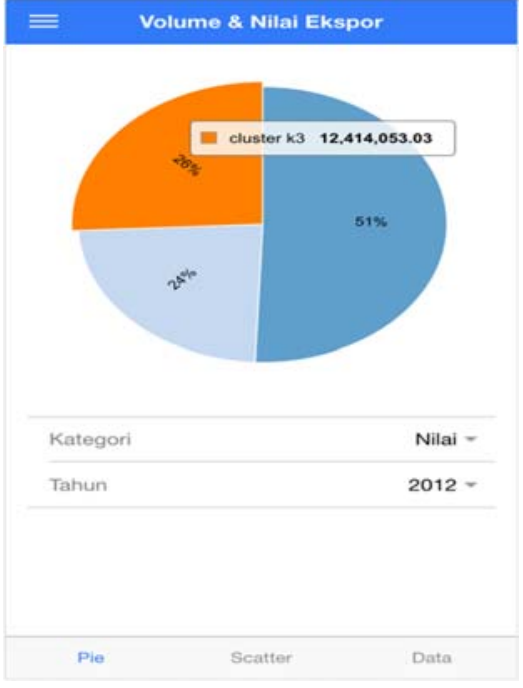

(b)

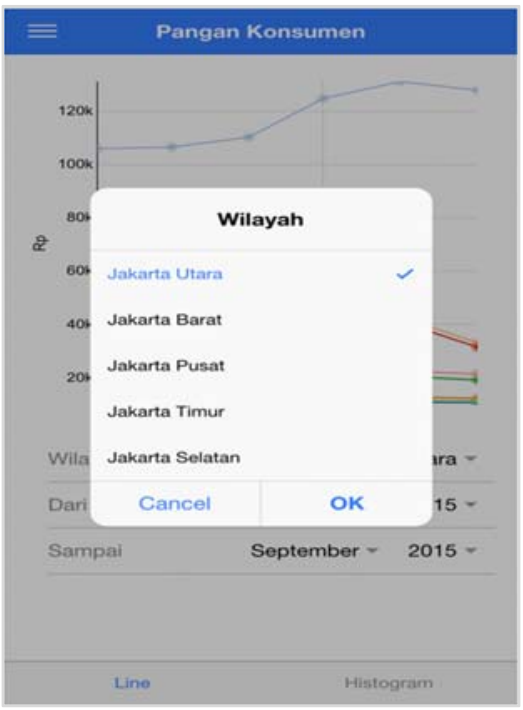

(d)

Lampiran Gambar 1. (a) Visualisasi line dan bar chart untuk data UMP pada Data 2; (b) Visualisasi Pie Chart untuk Data 7; (c)

Pengguna dapat melakukan filtering dari hasil keluaran $k$-Means yang diaplikasikan pada Data 7; (d) Pilihan yang bisa dilakukan pada line chart dari Data 10 